\title{
A POSZTPARTUM DEPRESSZIÓ EVOLÚCIÓS MEGKÖZELÍTÉSEI
}

\author{
SZITA BERNADETT \\ Semmelweis Egyetem, I. sz. Szülészeti és Nôgyógyászati Klinika \\ E-mail: szitabernadett@t-online.hu \\ Beérkezett: 2015. június 22. - Elfogadva: 2015. november 24.
}

\begin{abstract}
A posztpartum depresszió (PPD) súlyos népegészségügyi problémát jelent világszerte, amely a nók mintegy 10-15\%-át érinti a szülést követố idôszakban. A PPD jelentôsebb rizikófaktorai: alacsony társas támogatottság, alacsony szocioökonómiai státusz, koraszülött vagy egyéb perinatális komplikációkkal világra jövó újszülött és pszichiátriai zavarok az anya anamnézisében. A kórkép etiológiája nem teljesen tisztázott, kialakulásában biológiai és pszichoszociális faktoroknak egyaránt szerepet tulajdonítanak. Az evolúciós szemléletü megközelitések szerint a PPD nem patológiának, hanem egy olyan adaptív válasznak tekinthetô, amely az esetlegesen bekövetkező reproduktív fitneszveszteségrôl nyújt információt az anyának, és arra ösztönzi, hogy mérlegelje, folytassa-e vagy felfüggessze az utódgondozást. E szerint az utódgondozás az anya részéról korántsem automatikus, hanem a reproduktív költségek és nyereségek függvényében alakul. A tanulmány a PPD evolúciós elméleteit tekinti át, az azokat támogató és cáfoló újabb kutatási eredmények ismertetésével együtt.
\end{abstract}

Kulcsszavak: posztpartum depresszió, evolúciós pszichológia, szülöi befektetés, reprodukció, utódgondozás

\section{BEVEZETÉS}

Az unipoláris depresszió az egyik leggyakoribb és legnagyobb társadalmi jelentôségú pszichiátriai zavar. A WHO becslései szerint 2020-ra a világon, így Magyarországon is a második leggyakrabban munkaképtelenséghez vezetô betegség lesz (Murray és Lopez, 1996). Hazai vizsgálatok szerint a kórkép élettartam, 1 éves és 1 hónapos prevalenciája a felnốtt lakosság körében 15,1\%, 7,1\% és 2,6\% (Szádóczky, Papp, Vitrai és Füredi, 2000). Az unipoláris major depresszió minden életkorban kialakulhat, de jellemzóen a 20-30 életévek között veszi kezdetét, tipikusan ismétlődő (rekurrens) vagy króni- 
kus lefolyást mutatva egyre súlyosabb tüneti kép kíséretében (Tringer, 2010; Szekeres, Bai-Nagy és Rihmer, 2015).

Az unipoláris hangulatzavarok elôfordulása a nôk körében közel kétszerese a férfiakénak (Wisner, Chambers és Sit, 2006). Jelentôs részüknél az elsô depressziós epizód a perinatális idôszakban alakul ki (Rubertsson, Wickberg, Radestad, Hildingsson és Waldenstrom, 2005). A szülést követôen a nôk mintegy 80\%-a tapasztalja meg a gyermekágyi lehangoltság enyhébb formáját, az ún. baby bluest (Workman, Barha és Galea, 2012), a posztpartum depresszió (PPD) pedig 10-15\%-ukat érinti (O’hara, 2009).

\section{A PPD TÜNETTANA ÉS KEZELÉSE}

A PPD-t a Mentális Betegségek Diagnosztikai és Statisztikai Kézikönyvének 5. kiadása (DSM-V) nem önálló kórképként, hanem a major depresszió egy altípusaként kezeli, amelyre a „szülés körüli (peripartum) kezdettel” megjelölés alkalmazható. A major depreszsziós epizód diagnózisa akkor állapítható meg, ha az alábbi tünetek közül legalább öt ugyanazon kéthetes idôszak során fennáll, melyek közül az elsố két tünet valamelyikének mindenképpen jelen kell lennie: 1. depressziós hangulat, 2. az érdeklôdés/ örömkészség elvesztése, 3. jelentôs fogyás vagy hízás, 4. inszomnia vagy hiperszomnia, 5. pszichomotoros nyugtalanság vagy gátoltság, 6. fáradtság, anergia, 7. értéktelenség, búntudat érzése, 8. csökkent gondolkodási, döntési és koncentrációs képesség, 9. halállal vagy öngyilkossággal kapcsolatos gondolatok, terv, kísérlet. A tünetek klinikailag jelentôs szenvedést vagy az életvitel fontos területeinek károsodását okozzák, és nem magyarázhatók jobban gyászreakcióval, egyéb pszichés zavarral, valamint nem tulajdoníthatók szer vagy más szomatikus állapot élettani hatásainak, és az anamnézisben nem szerepel mániás vagy hipomániás epizód (American Psychiatric Association, 2013). A „szülés körüli kezdettel” jelölés akkor adható meg, ha a fenti tünetek a terhesség során vagy a szülést követô négy héten belül kezdődtek.

A PPD fókuszában jellemzôen az anyaszerep, az újszülött elfogadásának vagy ellátásának kudarcélménye áll. A DSM-V külön feltünteti, hogy a kórképet sokszor kíséri súlyos szorongás vagy pánikroham. Nem tesz említést ugyanakkor a szintén gyakran előforduló - a gyermek bántalmazásával kapcsolatos - kényszergondolatokról, amelyeket tényleges agresszív cselekedetek általában nem követnek (Doucet, Dennis, Letourneau, Blackmore, 2009). A csecsemőgyilkosság elsôsorban a hallucinációkkal vagy téveszmékkel járó pszichotikus állapotokban fordulhat elố. Ugyan a DSM-V alapján pszichotikus tünetek major depressziós epizód során is jelentkezhetnek, a kutatási adatok zöme arra utal, hogy a kórkép a bipoláris zavarok egyik altípusa lehet, és mind a lefolyás, tünetmintázat, etiológia tekintetében élesen elkülönül a PPD-tôl (Kendell, Chalmers és Platz, 1987, Chaudron és Pies, 2003, Sit, Rothschild és Wisner, 2006).

A gyermekágyi depresszió kezelése függ a tünetek súlyosságától; míg az enyhe depressziós epizód pszichoterápiás beavatkozással kezelhető, addig súlyos depresszió esetén feltétlenül szükséges gyógyszeres terápia alkalmazása is, ami legtöbb esetben az anya hospitalizációjával jár együtt (Fitelson, Kim, Baker és Leight, 2011). 


\section{A PPD ETIOLÓGIÁJA}

A posztpartum depresszió etiológiája nem teljesen tisztázott, kialakulásával kapcsolatban biológiai és pszichoszociális kockázati tényezôkrôl beszélhetünk. A biológiai faktorok közül a genetikai prediszpozíció, a neuroendokrin és pszicho-neuro-immunológiai változások hatásai emelhetốk ki (Corwin és Pajer, 2008; Corwin, Kohen, Jarrett és Stafford, 2010; Brummelte és Galea, 2016).

Mivel a terhességre és a gyermekágyas idôszakra a nemi hormonok vérszintjének nagyfokú ingadozása jellemzô, a PPD-vel kapcsolatban elsôsorban két gonadális szteroidhormon, az ösztrogén és a progeszteron szerepére irányult a legnagyobb figyelem az elmúlt évtizedek során (Brummelte és Galea, 2016). Az ezekkel kapcsolatos elméletek a terhesség során többszörösére emelkedô ösztrogén- és progeszteronszint szülést követố hirtelen visszaesésével magyarázzák a hangulatzavarok kialakulását (Bloch, Daly és Rubinow, 2003). Az elképzelést kutatási eredmények nem tudták egyértelmúen igazolni, ami annak is köszönhetố lehet, hogy a tüneteket nem a gonadális szteroidok szérumszintjének eltérései, hanem az azokra adott normálistól eltérố neurotranszmitter válasz okozza, a gonadális hormonok vérszintjének változásai ugyanis szoros kapcsolatban állnak a szerotonerg rendszer aktivitásával (Bethea, Lu, Gundlah és Streicher, 2002).

A PPD pszichológiai magyarázatai abból indulnak ki, hogy a terhesség és a gyermekágyas idôszak normatív krízisállapotnak tekinthetô, amelyet kísérő szomatikus, pszichés és szociális szerepekben bekövetkezô változások próbára teszik az egyén megküzdố képességét (Rapoport, 1963; Kovácsné Török, 2010). A krízishelyzet adekvát megoldása teszi lehetôvé az anyaszerep betöltését, egyben gazdagítja a nô személyiségét és problémamegoldó repertoárját. Ellenkezô esetben valódi krízishelyzet alakulhat ki, ami a pszichés problémák - köztük a depresszió - kialakulását is eredményezheti (Rapoport, 1963; Kovácsné Török, 2010).

Kutatások a PPD legkonzisztensebb elốrejelzôinek az alacsony társas támogatottságot, szocioökonómiai státuszt, az újszülött rossz egészségi állapotát, valamint az anamnézisben szereplô pszichiátriai zavarokat találták (Halbreich, 2005, Vigod, Villegas, Dennis és Ross, 2010). A szociális tényezốk közül döntố fontosságú a család egzisztenciális helyzete. Az anyagi biztonság hiánya és a munkanélküliség egyértelmúen negatív hatást gyakorol a gyermekágyi hangulatra (Goyal, Gay és Lee, 2010). Szintén kiemelt jelentősége van a családi háttérnek és a partnerkapcsolat minôségének, amely a megfelelố fizikai, emocionális támogatás révén befolyásolhatja az anya hangulatát és megküzdési képességét (Török és Szeverényi, 2007). Az intrapszichés tényezôk közül a legnagyobb kockázatot a kórtörténetben előforduló pszichés zavarok - elsôsorban a major depresszió és a premenstruációs szindróma - jelentik (Robertson, Grace, Wallington és Stewart, 2004, Sylvén, Ekselius, Sundström-Poromaa és Skalkidou, 2013). A korábbi depressziós epizód - a pszichológiai megközelítések szerint - az alacsonyabb önértékelés, nagyobb szenzitivitás és kevésbé hatékony problémamegoldó készségek révén fokozza a depresszió kialakulásával szembeni sérülékenységet ebben a kihívásokkal teli idôszakban (Hickey, Boyce, Ellwood és Morris-Yates, 1997). Taylor (1996) a minôsítố folyamatokat szerepére hívta fel a figyelmet. E szerint a PPD-s nốk saját anyasággal és gyermekükkel kapcsolatos érzéseiket elfogadhatatlannak ítélik 
meg, összehasonlítva az általuk elfogadhatónak hitt érzésekkel, melyeket nagymértékben meghatároznak a társadalmi elvárások is. A szülészeti faktorok közül a súlyosabb komplikációk, a koraszülött vagy rossz egészségi állapotú gyermek, a szülés negatív megélése és a tápszeres táplálás növelik meg PPD kialakulásának kockázatát (Vigod és mtsai, 2010; Blom, Jansen, Verhulst, Hofman, Raat, Jaddoe és mtsai, 2011). Egy egészségkárosodással világra jövô gyermek esetében magától értetôdô, miért okozhat lehangoltságot, depressziót, míg a szülés rosszabb megélése és a szoptatási nehézségek esetében a kudarcélmény járulhat hozzá a negatívabb hangulathoz (Gagliardi, Petrozzi és Rusconi, 2012).

Összességében elmondható, hogy a PPD etiológiája - mai ismereteink szerint többtényezôs, amelyben a biológiai és pszichoszociális faktorok egyaránt szerepet kapnak (Kovácsné Török, 2010). A tünetek megjelenéséhez a hormonális változások az egyén genetikai, neuroendokrin és pszichológiai sérülékenységének függvényében járulhatnak hozzá.

\section{EVOLÚCIÓS SZEMLÉLET A PPD ÉRTELMEZÉSÉBEN}

Az evolúciós pszichológia képviselôi szerint annak ellenére, hogy a posztpartum depressziót mentális betegségként tartjuk számon, az arra jellemzô kognitív, emocionális és viselkedéses változások evolúciós szempontból valójában adaptívak, funkciójuk a fajfenntartást szolgálja (Hagen, 2011).

Az evolúciós pszichológia elméletei két nagyobb csoportra, az adaptációs és a melléktermék-hipotézisekre oszthatók. Míg előbbi egy testi vagy pszichés sajátosságot azzal magyaráz, hogy az evolúció során, természetes úton választódott ki, mert ôseink reprodukciós sikerét növelte, utóbbi szerint az adott tulajdonság soha nem járt reprodukciós elônnyel, mindössze bizonyos körülmények hatására, mintegy mellékesen jött létre és maradt fenn (Bereczkei, 2003).

Amint a fentiekból is kiderül, a PPD-t az evolúciós pszichológia képviselôi az adaptációs megközelítés elméleti keretein belül értelmezik. A PPD evolúciós magyarázataiban a következô közös vonások fedezhetôk fel: evolúciós szempontból adaptív, célja a fajfenntartás, univerzális, tehát minden társadalomban megtalálható, valamint a kórkép kialakulásában a hormonális változásoknak nincs szerepe (Harris, 1994; O’hara, 2009). A legtöbb elmélet közös alapvetése továbbá, hogy sem az állatvilágban, sem az embereknél nincs feltétlen utódgondozás; bizonyos feltételeknek teljesülniük kell ahhoz, hogy az anya energiát fektessen az újszülött ellátásába, különben az utódgondozás reproduktív szempontból nem térül meg, tehát nem szolgálja a fajfenntartást (Tracy, 2005).

\section{A PSZICHÉS FÁJDALOM HIPOTÉZISE}

A pszichés fájdalom elmélete szorosan kapcsolódik a fizikai fájdalom evolúciós magyarázatához, amely szerint a fájdalom emocionális aspektusa, a szenvedés azért adaptív, mert az averzív, potenciálisan szöveti károsodást okozó inger jelenlétérôl informálja az 
egyedet. Ennek következménye egyrészt az aktuális cselekvés leállítása és kompenzáló mechanizmusok aktiválása (pl. a sérülés ellátása), a jövôben pedig az ártalmas inger elkerülése (Nagasako, Oaklander és Dworkin, 2003).

A pszichés fájdalom hipotézise szerint a szomorúság érzése tulajdonképpen ugyanazt a cél szolgálja, mint a fizikai fájdalom, csak nem a testi épséget, hanem a pszichés integritást veszélyeztetô ingerekrốl ad tájékoztatást, különös tekintettel azokra a potenciálisan averzív ingerekre, amelyek a szociális szférából érkeznek (Thornhill és Thornhill, 1989). A PPD vonatkozásban a pszichés fájdalom teóriája azt implikálja, hogy a szomorúság, lehangoltság érzése informálja az anyát arról, hogy adott feltételek mellett az utódgondozásba fektetett energia nem fog megtérülni, mert például a környezeti vagy szociális feltételek, esetleg az újszülött állapota miatt kevés az esély a gyermek túlélésére (Thornhill és Furlow, 1998). Ezért történik meg az aktuális cselekvésrôl, vagyis az újszülött ellátásáról, a kompenzációs viselkedésformákra való áttérés, például a társas segítségnyújtásra való igény kifejezése.

Az elméletet támogatják azok a kutatási eredmények, amelyek a PPD elórejelzójének a rossz szociális körülményeket, alacsony társas támogatottságot, valamint a szülészeti komplikációkat találták (Halbreich, 2005). Ugyanakkor nem ad kielégítô magyarázatot a lehangoltság érzésén túl a depresszió egyéb tüneteire: az általános aktivitáscsökkenésre, az anergiára, a testsúly vagy az alvás változására és a szuicid gondolatokra. Nem válaszolja meg továbbá azt a kérdést sem, hogy a PPD miért tekinthetô adaptívnak a fajfenntartás szempontjából (Hagen, 2011).

\section{AZ „ÉLETTÖRTÉNET” ÉS A SZÜLŐI BEFEKTETÉS ELMÉLETE}

Az „élettörténet” hipotézise (Macarthur és Wilson, 1967) az evolúciós biológia és pszichológia egyik alapkövének tekinthetô. Az elmélet azokat a viselkedéses és fiziológiai stratégiákat írja le, amelyek a környezeti feltételekhez való alkalmazkodást szolgálják. Eszerint minden élôlény alapvetô célja élete során a túlélés és a szaporodás, illetve a két cél elérése közti optimális energiaelosztás megtalálása. Általánosságban, a reprodukcióra fordított energia a túlélési, növekedési, fejlôdési esélyeket rontja, míg a túlélésért tett erôfeszítések a szaporodási sikert csökkentik (Clutton-Brock, 1991). Az élet korai szakaszában az életben maradás és a fejlődés elsôbbséget élveznek, ivarérett korban pedig a szaporodás kerül elôtérbe (Austad, 1997). A szaporodási stratégiákat az vezérli, hogy életképes, reproduktív kort elérô utódokat lehessen nemzeni, ami kompromisszumot igényel a jelenlegi és jövôbeli szaporodás, az utódok száma és a rájuk fordított idő között. A ráfordítás mennyiségét a környezeti tényezôk is nagyban befolyásolják (Stearns, 1992).

Az élettörténet hipotézishez szorosan kapcsolódó „gyors-lassú kontinuum” teóriája szerint a túlélés és reprodukció tekintetében gyors és lassú stratégiákat különböztethetünk meg. (Saether, 1988; Ellis, Figueredo, Brumbach és Schlomer, 2009). A kedvezôtlen vagy kiszámíthatatlan környezeti feltételek, a rövid várható élettartam, magasabb halálozási arány az úgynevezett „gyors stratégiának” kedvez, melynek lényege a rövid távú elônyök elôtérbe helyezése, mivel hosszabb távon a túlélés, szaporodás lehetôsége nem biztosított. A gyors stratégiára a több utód mellett megvalósuló kisebb 
szülôi ráfordítás jellemzô. A „lassú stratégia” esetében viszont az optimális környezeti feltételek megengedik a hosszabb távú tervezést, ami a reprodukció vonatkozásában kevesebb utódot, de nagyobb szülôi ráfordítást eredményez. A két stratégia az éloolény biológiai és pszichológiai-viselkedéses szabályozó mechanizmusait is meghatározza (Del Giudice, 2014).

Trivers szülőii befektetés teóriája (1972) az élettörténet-modell keretében a két nem eltérô párválasztási és utódgondozási stratégiáit írja le. Az elmélet abból indul ki, hogy a szülői ráfordítás kiegyenlítetlen a két nem részérôl; a nôsténynek jellemzốn több energiába kerül az utódnemzés és az utódok felnevelése. Trivers szerint, mivel az utódgondozás a nôstény részérôl nagyobb ráfordítást igényel, jelentôsebb mértékben ronthatja esélyeit a túlélésre, valamint a késôbbi szaporodásra. Emiatt a nôstény utódgondozása nem automatikus, hanem csak akkor valósul meg, ha bizonyos feltételek lehetôvé teszik, hogy az energiabefektetés reproduktív szempontból megtérüljön. Az anyának ezért fel kell mérnie, hogy az újszülött túlélési esélyei megfelelôek-e, és elérhetô-e az apa részérôl az utód felneveléséhez szükséges ráfordítás. Amennyiben a gyermek túlélési esélyei vagy a szülôk erôforrásai elégtelenek, az utódgondozás nagy valószínúséggel háttérbe fog szorulni, például az újszülött elhanyagolása vagy elutasítása révén.

Beaulieu és Bugental (2008) szerint a fenti modell azzal egészíthetô ki, hogy a szülook erőforrásai és a gyermek túlélési esélyei egyszerre határozzák meg az utódgondozásba fektetett energiákat, de nem additív, hanem „ha..., akkor” elv alapján. Ha tehát a szülook kevés erôforrással rendelkeznek, a rossz túlélési esélyú gyermek nem, vagy csak kevés ráfordítást kap. Ugyanakkor, ha a szülók jelentôs eróforrásokkal bírnak, több energiát fognak fordítani a rossz egészségi állapotú újszülöttre is, mivel az nem veszélyezteti a késôbbi utódokról való gondoskodást. Kutatások szerint azokban a térségekben, ahol alacsonyabb az életszínvonal, jellemzóen kevesebbet fordítanak a rossz egészségi állapotú csecsemôk életben tartására és gondozására, míg a jóléti társadalmakban kiemelkedően sokat invesztálnak a rosszabb életkilátású gyermekek ellátásába is (Bugental és Happaney, 2004).

A szüloói befektetés fenti két hipotézise a gyors-lassú kontinuum elméletén belül is értelmezhetô, miszerint abban az esetben, ha a külsô körülmények kedvezôtlenek vagy kiszámíthatatlanok - legyen szó akár a környezeti erôforrásokról vagy a partner támogatásáról - a szülốk magatartását a gyors stratégia fogja meghatározni, amelyben az utódgondozásra fordított nagyobb energiabefektetés nem kifizetôdô.

Hagen (1999) szerint a szülői befektetés elmélete magyarázatot ad arra, miért jelent kockázatot az alacsony társas támogatottság és az újszülött rossz egészségügyi állapota a PPD kialakulásával szemben, és a depressziós tünetegyüttes mért nyilvánulhat meg olyan magatartásformákban, mint az utód elutasítása és elhanyagolása. Ugyanakkor nem ad választ arra, hogy miért vezetnek ezek a körülmények a depresszió emocionális aspektusának - a szomorúságnak és lehangoltságnak - megtapasztalásához.

A PPD érzelmi komponensére Trivers elmélete valóban nem tér ki, Del Giudice (2014) interpretációjában a gyors-lassú kontinuum hipotézise azonban támpontot adhat az emocionális változások megértéséhez. A depresszív hangulat egyik fó célja, hogy a kockázat- és ártalomkerülố magatartást aktiválja abban az esetben, amikor a társas környezet kedvezőtlenné válik, ezzel elôsegítve, hogy a személy sérülékenyebb állapo- 
tában kevesebb veszélynek tegye ki magát (Nettle, 2009). Míg a férfiakat jellemzóen a státuszveszteség, addig a nôket a csökkent társas támogatás érinti érzékenyebben (Kendler, Myers és Prescott, 2005). Veszélyes vagy kiszámíthatatlan környezeti feltételek mellett a társas támogatás, illetve a közeli, stabil kapcsolatok hozzáférhetôsége jellemzően csökken, ami a nôket kiszolgáltatottabbá teszi a depresszív hangulat kialakulásával szemben. A PPD vonatkozásában mindez azt jelentheti, hogy azokban az esetekben, amikor a külsố körülmények kedvezôtlenek, esetleg a partner nem hozzáférhetô, az egyrészt a gyors stratégiának megfelelő gondozói magatartást aktiválhatja, másrészt a kedvezôtlen társas környezetre való érzékeny reagálásnak köszönhetôen a lehangoltság, depresszív hangulat kialakulását vonhatja maga után.

\section{A PPD „LEVÁLÁS” MODELLJE}

Hagen (1999) a szülői befektetés elméletéból kiindulva feltételezi, hogy a depresszióval járó lehangoltság informálja az anyát az általa elszenvedett reproduktív fitneszveszteségrôl, vagyis arról, hogy az utódgondozás költségei meghaladják az azokból származó nyereséget. A lehangoltság és az érdeklődés beszúkülése ront az anya-gyermek kötődés minôségén, ami miatt az anya könnyebben tud leválni az utódról és felhagyni a róla való gondoskodással.

A PPD-ben szenvedô anyáknál kontrollált körülmények között is megfigyelhetô, hogy több negatív affektust fejeznek ki, türelmetlenebbek, idegesebbek a gyermekükkel, viszont kevésbé érzékenyen reagálnak és nehezebben ismerik fel a csecsemô szükségleteit (Beck, 1995). Utánkövetéses vizsgálatok pedig igazolták, hogy PPD-s anyák gyermekei kevésbé biztonságosan kötôdnek (Murray és Cooper, 1996).

A preindusztriális társadalmakban a terhesség és a gyermeknevelés sokkal nagyobb ráfordítással járt, mint napjainkban (Wood, 1994). A nók lényegesen kevesebb energiatartalékkal rendelkeztek, ami a várandóság során sem gyarapodott jelentôsen; keveset vagy egyáltalán nem nôtt a testzsír-százalékuk. Ugyanakkor a szúkös környezeti erôforrások miatt körülbelül 3 évig szoptattak; az utód táplálékát - ezáltal az életben maradásának zálogát - ebben az idôszakban szinte kizárólag az anyatej jelentette. A szoptatás jelentôsen megváltoztatja az anyagcserét, mivel nagy energiafelhasználással jár, ami az anya alutápláltsága esetén nemcsak a tej elapadásához, hanem saját egészsége veszélyeztetéséhez is vezethet (Miller és Huss-Ashmore, 1989). A szoptatás tehát még a terhességnél is nagyobb ráfordítást igényel az anya részérôl. Ennek tükrében jobban érthetô, miért jelent egy rossz túlélési esélyekkel rendelkezô újszülött reproduktív fitneszveszteséget, és miért fontos, hogy az anya még idôben tudomást szerezzen erröl.

Hagen „leválás” modellje (1999) szerint a következô tényezôk korlátozhatják az anya utódgondozásra fordított energiáit.

1. Megfelelố mennyiségú vagy minôségú támogatás hiánya az apa vagy a környezet részérôl, ami szükséges lenne az utód felneveléséhez.

2. Az utód túlélési, illetve a reproduktív kort elérésének esélyei rosszak.

3. A gyermek felnevelését nehezítô vagy ellehetetlenítô környezeti feltételek (pl. kevés élelem). 
4. Egyéb körülmények, amelyek megkérdôjelezik az utódgondozásba fektetett energia reproduktív elônyeit, pl.

a. idôsebb, ezáltal jobb túlélési eséllyel rendelkezô utódok;

b. az anya saját túlélése, egészsége, fejlôdése, valamint a késôbbi gyermekvállalási esélye kerül veszélybe,

c. elérhetô ,jobb”, azaz reproduktív szempontból több nyereséggel kecsegtetô (pl. jobb génállománnyal rendelkezô, jobb feltételeket biztosítani tudó vagy az utódgondozásba többet invesztáló) partner.

Az elméletet támogatja, hogy kutatások szerint a partner hiánya, a párkapcsolati problémák, az alacsony társas támogatottság és szocioökonómiai státusz, a perinatális komplikációk, illetve az újszülött rossz egészségi állapota együtt járnak a posztpartum depresszió megnövekedett kockázatával (Logsdon és Mcbride, 1994; Halbreich, 2005; Vigod és mtsai, 2010; Jeong és mtsai, 2013).

Hagen (2002) szerint a PPD tünetegyüttese két szempontból is adaptív. Egyrészt, csökkenti az anya energiabefektetését az utódgondozásba akkor, amikor az reproduktív szempontból „nem kifizetôdô”, tehát nagy a valószínúsége, hogy nem térül meg, mert az utód nem éri meg a reproduktív kort. Másrészt, figyelemfelkeltô volta miatt megnövelheti a környezetből érkezó segítségnyújtást, például elôsegítheti, hogy a rokonok nagyobb részt vállaljanak az utódról való gondoskodásban. Utóbbinak fơként a preindusztriális társadalmakban volt funkciója, amikor az emberek kisebb - vadászó-gyújtögetô életmódot folytató - közösségekben éltek, és az olyan tünetek, mint a hiperszomnia, fáradtság, anergia, súlyveszteség, meglassultság, csökkent aktivitás és döntéshozatali képesség az egész csoportra nézve veszélyt jelentettek. A depresszív tüneteket mutató egyén emiatt társai részérôl nagyobb támogatásra és segítségnyújtásra számíthatott (Mcguire és Troisi, 1998).

\section{A PPD „ALKU” MODELLJE}

A PPD „alku” modellje (Hagen, 2002) lényegében a fenti hipotézis kiterjesztése, amelyben kiemelt hangsúlyt kap a depresszió figyelemfelkeltô és társas támogatást aktiváló volta. Olyan helyzetekben, amikor a másokkal való együttmúködés elkerülhetetlen, viszont a kooperáció magas költségekkel jár az egyén számára, a depresszió egyfajta alkudozó viselkedésnek tekinthetô (Birkás, 2014). Egy pár esetében szigorú társas normák írják elô, hogy mindkét szülô részt vegyen az amúgy nagy ráfordítással járó utódgondozásban, tehát a kooperatív helyzetból való kilépés nehezített (pl. szociális környezetük elutasítja).

Hagen feltételezi, hogy a PPD egyes tüneteinek funkciója az, hogy a környezet, elsôsorban a partner és a rokonok részérôl többlettámogatást sikerüljön „kialkudni”. Hagen szerint ez a mechanizmus a munkások sztrájkjához hasonlítható, akik a munka beszüntetésével próbálnak meg béremelést vagy munkaidô-csökkentést kiharcolni. A posztpartum depressziós anyák ennek megfelelően úgy csökkentik az utódgondozással kapcsolatos költségeket, hogy visszatartják saját ráfordításaikat, és 
ezzel igyekeznek elérni a partner vagy a szúkebb családi környezet részérôl, hogy az addig rejtett erôforrásaikat mozgósítsák, és nagyobb részt vállaljanak a gyermekrôl való gondoskodásban.

A hipotézis tesztelése érdekében Hagen (2002) 129 kisgyermekes családot vont be kutatásába, amelyben a pár mindkét tagjánál felmérte saját és környezetük abortuszszal kapcsolatos attitúdjeit, jelenlegi és korábbi szexuális sikereiket (pl. szexuális partnerek száma), párkapcsolatuk minôségét, a felek „munkamegosztását” a várandósság elôtt és után, és azt, hogy a jelenlegi terhesség tervezett volt-e. Hagen feltételezései a következók voltak:

1. A férfiak abortuszellenes attitûdje pozitívan korrelál a PPD elófordulásával, de csak abban az esetben, ha a terhesség nem volt tervezett. Hagen szerint, ha a pár férfi tagja elutasító az abortusszal szemben, a nőre nagyobb nyomás nehezedik, hogy a nem kívánt terhességet megtartsa. Mivel a magzat elvetetése vagy késóbbi elhagyása súlyos következménnyel járna, a depressziós tünetegyüttes mintegy kiskapuként szolgálhat arra, hogy az anya az utódgondozás terhe alól, még ha részben is, de mentesüljön.

2. A szexuálisan sikeresebb férfiak magasabb depresszió pontszámot érnek el, ellentétben a nôkkel, ahol ez a tényezô nincs hatással a hangulatra. Ez a feltételezés a férfiak és nôk eltérô párválasztási és szaporodási stratégiájából következik. A férfiak számára a monogámia, illetve az utódgondozás „terhe” reproduktív fitneszveszteséggel jár, különösen akkor, ha az amúgy sikeres férfi könnyen hozzáférhet több partnerhez. Nôk esetében a hipotézis nem állhatja meg a helyét, hiszen a gyermekvállalás költségei miatt az életképes utódok száma eleve korlátozott.

3. Depresszió megléte az egyik fél esetében megnöveli a másik fél ráfordításait az utódgondozásban. Ez a feltételezés a PPD „alku” modelljének legfontosabb kitételét hivatott igazolni.

4. Azok a nôk, akiknek kisebb esélyük van a késóbbi gyermekvállalásra (pl. idôsebb korban születik meg elsô gyermekük) még egyéb kockázati tényezôk megléte esetén sem veszélyeztetettek a PPD kialakulásának tekintetében.

A fenti feltételezéseket a kutatás eredményei igazolták, kivéve az elsô hipotézist; az apa abortusszal szembeni korlátozó attitúdje csak a szélsô értékek kontrollálása után mutatott korrelációt az anya depresszió pontszámával. A nôk életkora és a PPD elófordulása közti negatív együttjárást egy késôbbi, nagyobb mintán végzett kutatás is megerôsítette, amely során több ismert rizikófaktort is kontrolláltak (Bottino, Nadanovsky, Moraes, Reichenheim és Lobato, 2012). A 811 fös mintán végzett keresztmetszeti kutatás igazolta, hogy a magasabb anyai életkor védôfaktort jelent a PPD-vel szemben, a szocioökonómiai státusz, végzettség, párkapcsolati viszonyok, a saját vagy a partner alkohol-, illetve drogfogyasztása és a családon belüli erôszak előfordulásától függetlenül. Az egyetlen változó, amelynek interakciós hatása volt, az a családban lévô gyermekek száma. Ezt leszámítva, a PPD kockázata minden évvel 4\%-kal csökkent. 


\section{AZ ANYAI VÁLASZKÉSZSÉG ÉS A FOLYTONOS GONDVISELÉS ELMÉLETE}

Crouch (1999) a fenti szerzôk elméleteitôl jelentôsen eltérô hipotézist fogalmazott meg a PPD-vel kapcsolatban. Már a PPD terminusának létjogosultságát is megkérdójelezi a nagy változatosságot mutató tüneti repertoár és a nem egyértelmú diagnosztikai kritériumok miatt. Ehelyett a posztnatális stressz és depresszió (PNSD) fogalmának bevezetését javasolja; ez magában foglal minden olyan állapotot, amely a puerperium idôszakában fellépó emocionális és viselkedési zavarral jár. Crouch szerint a PNSD tünetei, amelyeket patológiásnak minôsítünk, valójában adaptívak, sốt hasznosak, mivel elsôsorban a gyermek szükségleteire adott anyai válasz részét képzik. Tehát, amit az anya érez, és ahogyan cselekszik, annak az újszülött fóbb igényeire kell reflektálnia, amelyek a szülést követô idôszakban a csecsemó fiziológiai és biztonsági szükségleteit foglalják magukban.

A tradicionális társadalmakban az anya és a gyermek között már a születés pillanatától kezdve fizikai értelemben is sokkal szorosabb kötelék volt. A Kung Sun törzsben a nôk a mai napig segítség nélkül szülik meg gyermekeiket, a köldökzsinórt nem vágják el, hanem megvárják, hogy természetes úton leváljon. Az anyák kisgyermeküket évekig szoptatják, és mindenhová magukra kötve hordozzák óket (Barr, 1990). Mivel ezek a körülmények biztosítják az anya folytonos válaszkészségét és az újszülött szükségleteinek szinte azonnali kielégítését, a csecsemô sokkal rövidebb ideig sír. A nyugati társadalmakban az erôteljesebb és hosszabb idôtartamú sírás természetesen következik az anya fizikai távolságából, hiszen ha az anya nehezebben elérhetô, nagyobb intenzitású szükségletkifejezés válik indokolttá.

Amennyiben elfogadjuk, hogy a folytonos gondviselés és szükségletkielégítés jelenti azt az adaptív, korai anya-gyermek kapcsolatot, amely az evolúció során kiválasztódott, akkor feltételezhetô, hogy az ettôl jelentôsen eltérô csecsemôgondozás, mind a gyermek, mind az anya reakcióiban zavart okozhat. Tehát nemcsak a gyermek fog hosszabb ideig sírni, hanem az anya érzelmi és viselkedéses válaszai is erôteljesebbek lesznek, például többet fog aggodalmaskodni, lehangoltabb lesz és nehezebben fog aludni. Ez a probléma nemcsak akkor élezôdik ki, amikor a csecsemô - például rossz egészségi állapot miatt - valóban többet sír vagy nehezebb temperamentumú, hanem, ha az anya túlbecsüli a gyermek jelzéseit, tehát az újszülött reakciói és az anya válaszkészsége nincs összhangban egymással. Ez a reciprok kapcsolat számos tényezô következtében sérülhet, például az anya gyakorlatlansága (elsố gyermek) vagy a gyermek speciális igényei (koraszülés vagy perinatális sérülés) miatt (Crouch, 2002).

A zavartalan korai anya-gyermek kapcsolat kialakítását szintén nehezíti, hogy napjaink nyugati társadalmaiban hiányoznak azok a tradíciók, amelyek alapján a nôket már kislány koruktól kezdve felkészítették a késóbbi gyermekvállalásra, másrészt a kismamáknak nyújtottak segítséget az újszülött gondozásában. A XX. század folyamán - a kis közösségek felbomlásával és az individualizáció térhódításával - ezek a hagyományok fokozatosan eltûntek, az anyaság és az utódgondozás pedig „magánüggyé” vált (Mitteraurer, 1994). Az anya saját felelôssége a gyermek ellátásában jelentôsen megnôtt, ami magyarázatot ad arra is, miért jelent nagy kockázatot a PPD kialakulása szempontjából a partner, illetve a szúkebb környezet elégtelen támogatása. Crouch (2002) szerint a társas támogatottság hiánya legfóképpen azért problémás, mert az anya nem 
kap segítséget, tanácsot, útmutatást abban, hogyan lássa el a csecsemôt, ami fóként az elôször szülố nôk esetében zavarhatja meg a korai anya-gyermek kapcsolatot. Crouch szerint a korábbi mentális problémák is azért lehetnek a PPD kockázati tényezôi, mert az anya válaszkészségét, illetve csecsemôgondozási képességét ronthatják. A fentiek tükrében a PPD-t értelmezhetjük úgy is, mint egy adaptív választ, amely arra hívja fel a figyelmet, hogy az anya nem képes adekvátan ellátni az újszülöttet.

A gyermekágyi pszichés zavarok kezelésére Crouch - a folytonos gondviselés mintájára - az anya-gyermek kapcsolat szorosabbá tételét tekinti a legfontosabb terápiás intervenciónak.

Crouch hipotézisét célzottan vizsgáló kutatások nem születtek. Az elméletet támogathatja az a tény, hogy az elsố gyermek születése, a magzati szövôdmények és az alacsony társas támogatottság ismert rizikófaktorai a posztpartum depressziónak (Halbreich, 2005). A PPD és a korai anya-gyermek interakció és kötôdés sérülése közti kapcsolatra pedig már számos tanulmány hívta fel a figyelmet (Milgrom, Ericksen, Mccarthy és Gemmill, 2006; Ohoka és mtsai, 2014). Ellentmond a hipotézisnek - vagy legalábbis megkérdôjelezi ok-okozati összefüggéseit - a PPD kultúrafüggetlen, univerzális volta, és az a megfigyelés, hogy a törzsi közösségekben ugyanazok a pszichoszociális változók korrelálnak a PPD megjelenésével, mint a nyugati társadalmakban (Hagen és Barrett, 2007).

\section{A TÁPSZERES TÁPLÁLÁS ÉS A PPD KAPCSOLATA}

A PPD kialakulásával kapcsolatban az elmúlt időszakban a szoptatás hiányával, illetve az újszülött tápszeres táplálásával összefüggésben születettek evolúciós szemléletú megközelítések. Számos kutatás igazolta a szoptatás idôtartamának és a PPD előfordulásának negatív korrelációját (Warner, Appleby, Whitton és Faragher, 1996; Hatton, 2005; Dennis és Mcqueen, 2009). Minden bizonnyal nem egyszerú ok-okozati kapcsolatról van szó; a szoptatási nehézség, a kudarcélmény megnöveli a posztpartum depresszió kockázatát (Gagliardi, Petrozzi, Rusconi, 2012), a depressziós anya pedig nagyobb valószínúséggel fog kevesebb energiát fordítani gyermeke természetes táplálására (Nishioka és mtsai, 2011). A szoptatás ugyanakkor önmagában védôfaktort jelenthet a posztpartum depresszióval szemben, amit az is igazol, hogy azokban a kultúrákban, amelyekben kizárólag anyatejjel táplálják az újszülötteket, a kórkép megjelenése átlagosan hat hónappal késôbbre tolódik ki (Labbok, 2001). Egyes becslések szerint a szoptatás akár 50\%-kal is csökkentheti a posztpartum depresszió kialakulásának esélyét (Gallup, Pipitone, Carrone és Leadholm, 2010).

Mawson és Wang (2013) úgy vélik, a szoptatás az endogén retinoidok (A-vitamint elôállító fehérjék csoportja) termelôdésének optimális szinten tartásával jelent védôfaktort a posztpartum depresszióval szemben. A retinoidok számos pszichiátriai kórformával hozhatók összefüggésbe, mint a depresszió, pszichózisok, valamint az allo- és autoagresszív cselekedetek (Bremmer és Mccafferey, 2008). Mawson és Wang (2013) szerint a mell szöveteiben felhalmozódó anyatej, amely szoptatás hiányában nem ürül ki, krónikus A-hipervitaminózist okoz az anya szervezetében, amely közvetlen okozója a depressziós tünetegyüttes vagy más pszichés zavarok kialakulásának a posztpartum 
idôszakban. A szerzôpáros szerint a szoptatás természetes védômechanizmust jelent a PPD-vel szemben, azáltal, hogy a szülés után kialakult magasabb retinoid koncentrációt csökkenti az anya szervezetében. A laktáció tehát mind az anya, mind az önmagáról gondoskodni képtelen újszülött szempontjából adaptív funkcióval bír.

A hipotézis empirikus tesztelése, a depressziós és mentálisan egészséges kismamák retinoid profiljának összehasonlításával válhatna lehetôvé, de erre eddig nem került sor. A hivatkozott cikkben mindazonáltal nem térnek ki arra a fontos kérdésre, hogy mennyiben befolyásolja a retinoid koncentrációt és a depresszió kialakulását az anyatej gyógyszeres elapasztása, amelyre a szoptatás tudatos felfüggesztése esetén kerül sor.

Egy meglehetôsen spekulatív elképzelés szerint a tápszeres táplálás azért válthat ki depressziós tünetegyüttest, mert a magzat elvesztéséhez kapcsolódó pszichológiai válaszokat aktiválja, egyrészt a tejelválasztás által serkentett hormonok (pl. oxytocin, prolaktin) alacsonyabb kiválasztódása, másrészt a szoptatásra jellemzó pszichológiai közelség hiánya miatt (Gallup és mtsai, 2010). Az elmúlt 100 évet leszámítva, a terhességet követôen a szoptatás elmaradása egyet jelentett a magzat elvesztésével, ami vetélés, halvaszületés vagy gyermekágyi halál miatt következhetett be. Egy magzat elvesztése - ha klinikai depressziót nem is mindig vált ki - rendszerint gyászfolyamattal jár együtt, ami tünetmintázatában közismerten hasonlít a depresszióra. A szoptatás hiánya tehát tudattalanul aktiválhatja azokat a pszichológiai mechanizmusokat, amelyek egy magzat vagy újszülött halálát követôen jelennek meg.

A hipotézist - a szerzők szerint - a PPD és a szoptatás hiányának együttjárása mellett az is alátámasztja, hogy a lehangoltság, szomorúság megjelenése a csecsemô elválasztásakor sem ritka jelenség. Továbbá, saját kutatásuk során azt tapasztalták, hogy azok az anyák, akik tápszerrel táplálták gyermekeiket, gyakrabban vették fel ôket (Pipitone, Leadholm, Carrone és Gallup, 2009). Ez a megfigyelés szerintük párhuzamba állítható azzal a jelenséggel, ami szubhumán fốemlôsöknél figyelhetố meg, miszerint a nôstények hajlamosak felvenni és hosszabb idôn keresztül magukkal hordozni halott kicsinyüket (Warren és Williamson, 2004).

\section{A PPD „MISMATCH” ELMÉLETE}

A Hahn-Holbroock és Haselton (2014) szerzôpáros a PPD értelmezésére az evolúciós „összeférhetetlenség” vagy „mismatch” elméleti keretén belül tettek kísérletet. A „mismatch" teória megalkotói a modern civilizációs betegségek elterjedésének okát abban az ellentmondásban vélik felfedezni, ami a mai ember életmódja és a között a létforma között húzódik meg, amelyhez ôseink az évezredek során alkalmazkodtak (Gluckman és Hanson, 2006; Nesse és Williams, 1996). Tehát azok a feltételek, amelyek régen reprodukciós elônyt biztosítottak az emberek számára, egyre kevésbé hozzáférhetôk, illetve háttérbe szorulnak a mindennapi életvitelünkben.

Hahn-Holbroock és Haselton (2014) szerint a PPD tünetei a pszichés stresszre vagy egyes hiányállapotokra adott immunológiai válasz következményei, amelyek a szervezet gyulladásos folyamatainak aktiválása révén az úgynevezett „sickness behavior” tünetegyüttesét hozzák létre, amire a lehangoltság, érdeklôdés csökkenése, megnö- 
vekedett alvásigény, étvágytalanság, gyengeségérzés és a szociális interakcióktól való visszahúzódás jellemzô. A PPD és általánosságban a depresszió tünetei a fenti megközelítésben szintén adaptívnak tekinthetôk; funkciójuk egyrészt a szervezet energiatartalékainak megôrzése céljából az aktivitás csökkentése, másrészt az óvatosság, elôvigyázatosság fokozása révén a kezdeményezókészség visszaszorítása, ami az egyedet annak sérülékenyebb állapotában a potenciális veszélyektôl óvhatja meg (Dantzer, O'conner, Freund, Johnson és Kelley, 2008).

A szerzôpáros tanulmányában kiemeli a kedvezôtlen változásokat a táplálkozásban (magasabb kalória-, alacsonyabb tápérték- és omega-3-zsírsav-bevitel), szoptatásban, testmozgásban, napfények való kitettségben (alacsonyabb D-vitamin-szint), valamint a csecsemôgondozásban, mint a PPD kialakulásában részt vevó faktorokat. Egyes tényezóknél (táplálkozás, D-vitamin-szint) a közvetlen immunológiai hatások hangsúlyosabbak, például az omega-3 zsírsavak és a D-vitamin gyulladáscsökkentô és antidepresszív tulajdonságára is találunk adatot az irodalomban (Arora és Hobel, 2010; Cassidy-Bushrow, Peters, Johnson, Li és Rao, 2010; Markhus, Skotheim, Graff, Frøyland, Braarud, Stormark és mtsai, 2013). A fizikai aktivitás és szoptatás esetében a biológiai és pszichológiai vonatkozások egyaránt fontosak lehetnek, például a testmozgás a kedvezó élettani változások mellett a testképre, önképre gyakorolt hatásával is pozitívan befolyásolhatja a hangulati élet alakulását (Lucassen, Meerlo, Naylor, Van Dam, Dayer, Fuchs és mtsai, 2010). A csecsemôgondozás tekintetében pedig a közösségi és családi segítségnyújtás szerepe a pszichés stressz csökkentésében jelenthetett védôfaktort a depresszió kialakulásával szemben (Hahn-Holbrook, Dunkel Schetter, Chander és Hobel, 2013).

Habár Hahn-Holbroock és Haselton elmélete a szerzók szerint sem ad teljes körú magyarázatot a PPD jelenségére, a tekintetben egyedülálló az evolúciós megközelítések között, hogy kísérletet tesz a posztpartum depresszió kialakulásában feltételezett biológiai mechanizmusok integrálására az evolúciós paradigmába. Az immunológiai folyamatok és a „sickness behavior” szerepének vizsgálata a major depresszió és a PPD patogenezisében pedig egyaránt kitüntetett figyelmet kapott az elmúlt években (Gleicher, 2007; Corwin és Pajer, 2008).

\section{A PPD KULTÚRKÖZI VIZSGÁLATAI}

A posztpartum depresszióval kapcsolatos kultúrközi vizsgálatok a következô igénnyel születtek:

1. a PPD univerzális voltának igazolása;

2. a PPD tünetmintázatában meglévô eltérések azonosítása, és annak vizsgálata, hogy azok hogyan illeszthetốk be a PPD evolúciós szemléleti keretébe;

3. azoknak a kisebb, törzsi közösségekben lévố rituáléknak, tradícióknak a megismerése, amelyek védelmet jelenthetnek a PPD-vel szemben.

Hagen és Barrett (2007) az Andok hegységben élő shuar indiánok körében végeztek kutatást azzal a céllal, hogy igazolják a PPD emocionális aspektusának, a lehangoltságnak kultúra-független, univerzális voltát. A shuar indiánok törzse kis létszámú, rossz 
életkörülmények között élô emberek közössége, akikre a környezeti hatások közvetlenül és nagymértékben kihatnak, például a nagyobb családokban felnövô gyermekek súlya, testzsírszázaléka, izomtömege és csontozatuk fejlettsége jelentôsen alulmúlja a kisebb családok gyermekeiét. A kutatók célja az volt, hogy megvizsgálják, a shuar nôk is tapasztalnak-e negatív emóciókat a szülés után, és ha igen, magyarázható-e ez a pszichés fájdalom hipotézisével. Mivel a shuar közösségben nem volt szó a depresszióra, arról kérdezték a nôket, hogy éreztek-e szomorúságot várandóságuk alatt vagy azt követôen, és ha igen, mivel magyarázzák azt. Ezenkívül felmérték, hogy a terhesség tervezett volt-e, vagy sem. Az eredmények szerint a vizsgálatba bevont nôk $62 \%$-a érzett szomorúságot a terhesség alatt, 33\%-uk pedig a szülést követően. A lehangoltságra adott indokok többsége magyarázható a pszichés fájdalom hipotézisével: a társas támogatottság hiánya (párkapcsolati problémák, a férj nem tért haza hosszabb utat követően), az erôforrások szúkössége (a gyermek ellátásához szükséges javak, pl. ruha, táplálék hiánya) és az újszülött egészségkárosodása. Szintén igazolódott az a feltevés, hogy nem kívánt terhesség esetén magasabb arányú a szülést követô lehangoltság elófordulása.

További kultúrközi vizsgálatok szinte kivétel nélkül megerôsítették a PPD univerzális voltát és az evolúciós szemlélet alapján elvárt prediktív tényezôk jelentôségét (Shimizu és Kaplan, 1987, Park és Dimigen, 1995, Felice, Saliba, Grech és Cox, 2004). A rizikófaktorok ugyan más képet mutatnak a fejlett nyugati társadalmakban, mint a törzsi népeknél, de jellemzôen ugyanahhoz a tematikához kapcsolódnak; így az alacsony szocioökonómiai státusz a PPD kockázata szempontjából egyenértékú az éhínséggel.

\section{ÖSSZEFOGLALÁS}

A posztpartum depresszió - az evolúciós paradigma szerint - inkább tekinthetô egy, az évezredek során természetes úton kiválasztódott adaptív válasznak, mint patológiás tünetegyüttesnek. Az elméletek jellemzően abból indulnak ki, hogy a terhesség és a szülés olyan megváltozott élethelyzetet teremt, amelyben bizonyos feltételek fennállása szükséges a megfelelő „helytálláshoz”. Ellenkezó esetben az anya vagy az újszülött testi épsége sérülhet. A PPD szélesebb körben támogatott evolúciós elméletei szerint azokban az esetekben, amikor a túlélés és szaporodás, mint két alapvetô ösztön, konfliktusba kerül, az egyednek választania kell, melyiket helyezze elôtérbe a várható reproduktív előnyök alapján. Az utódgondozás pedig abban az esetben háttérbe szorulhat, amikor a szülői (alacsony társas támogatottság) vagy a környezeti (kevés táplálék) erôforrások elégtelenek, illetve az újszülött túlélési esélyei rosszak (koraszülés) (Hagen, 1999, 2002; Hagen és Barett, 2007). A depressziós tünetegyüttes azért lehet adaptív, mert csökkenti az anya energiabefektetését az utódgondozásba akkor, amikor az „nem kifizetôdô”, tehát nagy a valószínúsége, hogy nem térül meg, mert az utód nem éri meg a reproduktív kort. Emellett, figyelemfelkeltő volta miatt megnövelheti a környezetbôl érkezô segítségnyújtást, például elôsegítheti, hogy az apa vagy a rokonok nagyobb részt vállaljanak az gyermekrốl való gondoskodásban. További lehetséges szerepe a szervezet energiatartalékainak megórzése céljából az aktivitás csökkentése, valamint a kezdeményezôkészség visszaszorítása, ami elôsegítheti, hogy az egyed sérülékenyebb állapotában kevesebb veszélynek tegye ki magát. 
A depresszió emocionális komponensének, a lehangoltság, szomorúság érzésének egyik funkciója lehet, hogy informálja az anyát arról, hogy változatlan feltételek mellett az utódgondozásba fektetett energia nem fog megtérülni. Másrészt a kockázat- és ártalomkerülố magatartást aktiválhatja, ami a kedvezôtlen külsố körülmények, alacsonyabb társas támogatás esetén ugyancsak a potenciális veszélyeknek való kitettség ellen nyújthat védelmet.

\section{ÉSZREVÉTELEK}

A PPD evolúciós magyarázatai - bár számos kutatási eredménnyel alátámaszthatók néhány fontos kérdés fölött átsiklanak. Az egyik ilyen a PPD egyik legerôsebb elôrejelzôje, az anamnézisben szereplő korábbi pszichiátriai zavar. Crouch (2002) ugyan kifejtette, hogy a korábbi pszichés zavarok az anya rosszabb csecsemőgondozási készsége miatt okozhatnak problémát, de nem ad magyarázatot arra, hogy miért pont a korábbi major depresszió és a premenstruációs szindróma (PMS) tekinthetốk a legfôbb pszichés kockázati tényezóknek (Robertson és mtsai, 2004; Sylvén és mtsai, 2013). A PMS hormonális érintettsége nem szorul magyarázatra, míg a major depresszióval kapcsolatban meg kell jegyezni, hogy klinikai és epidemiológiai vizsgálatok szerint a nôk szignifikánsan nagyobb kockázatnak vannak kitéve életük során a hangulatzavarok kialakulását illetôen, ami a pszichoszociális hatások mellett az eltérô endokrin múködésnek is köszönhetô lehet (Parry és Newton, 2001; Wisner és mtsai, 2006).

Ahogy korábban láthattuk, a depresszió egyik funkciója a veszélyek elkerülése lehet (Del Giudice, 2014). Ez a tulajdonság elônyösebb a nôk, mint a férfiak számára (Birkás, 2014). A gyermeknevelésben megnyilvánuló nagyobb energiaráfordítás miatt a nôknek saját és utóduk testi épsége és biztonsága fontosabb, a visszahúzódás pedig elôsegíthette, hogy ne tegyék ki magukat a táplálékgyújtés során fellépô veszélyeknek. Viszont a férfiak esetében, akiknek elsôdleges feladata az élelemszerzés és a búvóhely biztosítása volt, nagyobb hátrányt jelenthetett a depresszió (Birkás, 2014). Ez az evolúciós különbség pedig feltehetôen a nemi hormonok közvetítésével valósulhatott meg, elég csak a tesztoszteron újdonságkeresố magatartást elômozdító jellegére és antidepresszív hatására gondolnunk (Pope, Kouri és Hudson, 2000).

Az evolúciós szemléletû elméletalkotók mégis úgy vélik, hogy a PPD kialakulását nem befolyásolják a hormonális változások, amelyet legfőképpen azért tekintenek igazoltak, mert a posztpartum depressziós és mentálisan egészséges nók ösztrogénszintjében nem mutatható ki különbség (Tracy, 2005). Ezekben a vizsgálatokban azonban jellemzôen az ösztrogén vérszintjét mérik, miközben az endokrin múködés hatása az idegrendszerre ennél jóval összetettebb. A központi idegrendszer számos területén (hipotalamusz, amygdala) találhatók ösztrogén receptorok, amelyek szenzitivitása egyénenként eltérô lehet (Champagne, Weaver, Diorio, Sharma és Meaney, 2003; Mehta és mtsai, 2014). Genetikai kutatások pedig a humán alfa-ösztrogén-receptor-gén polimorfizmusa és a major depresszió élettartam-incidenciája közti kapcsolatra hívták fel a figyelmet (Sundermann, Maki és Bishop, 2010; Ryan és mtsai, 2011, 2012). Leegyszerúsítve, a hormonális változások hozzájárulhatnak a pszichés zavarok kialakulásához azoknál a nôknél, akiknek a központi idegrendszere érzékenyeb- 
ben reagál a megváltozott endokrin feltételekre (Deecher, Andree, Sloan, Schechter, 2008). Ezt az elképzelést igazolják azok a kutatások, amelyek kapcsolatot találtak a premenstruációs szindróma, a posztpartum depresszió, valamint a menopauza során fellépố pszichés zavarok élettartam elôfordulása között (Freeman és mtsai, 2004; Woods és mtsai, 2008).

Szintén felmerül a kérdés, hogyan értelmezhetô a PPD evolúciós szemléleti keretében a mesterséges megtermékenyítés útján fogant terhességek és a PPD prevalenciája közti korreláció (Fisher, Hammarberg és Baker, 2005). Hiszen - akárcsak a magasabb anyai életkorban, különösen az elsô gyermeküket ilyenkor váró nôknél - fenti esetben is nagyobb reproduktív fitnesznyereséggel kell számolni, mivel a meddôségi problémáknak köszönhetôen a késôbbi gyermekvállalás esélye jelentôsen romlik.

A fentiek miatt célszerú lenne a további evolúciós szemléletú kutatások és elméletalkotások során figyelembe venni a depresszió nemi különbségeivel kapcsolatos pszicho-neuro-endokrinológiai kutatások eredményeit és megkísérelni a PPD mögött esetlegesen meghúzódó biológiai folyamatokat beilleszteni az evolúciós paradigmába.

\section{IRODALOM}

American Psychiatric Association (2013). Diagnostic and Statistical Manual of Mental Disorders, 5th Edition: DSM-5. Washington, DC: American Psychiatric Publishing.

Arora, C. P., \& Hobel, C. J. (2010). Vitamin D - a novel role in pregnancy. Biopolymers \& Cell, 26, 97-104.

Austad, S. N. (1997). Comparative aging and life histories in mammals. Explorative Gerontology, 32(1-2), 23-38.

Barr, R. G. (1990). The early crying paradox: A Modest Proposal. Human Nature, 1, 355-389.

Beaulieu, D. A., \& Bugental, D. (2008). Contingent parental investment: an evolutionary framework for understanding early interaction between mothers and children. Evolution $\mathcal{E} \mathrm{Hu}$ man Behavior, 29(4), 249-255.

Beck, C. T. (1995). The effects of postpartum depression on maternal-infant interaction: a metaanalysis. Nursing Research, 44, 298-304.

Bereczkei T. (2003). Evolúciós Pszichológia. Budapest: Osiris Kiadó.

Bethea, C. L., Lu, N. Z., Gundlah, C., \& Streicher, J. M. (2002). Diverse actions of ovarian steroids in the serotonin neural system. Frontiers in Neuroendocrinology, 23(1), 41-100.

Birkás B. (2014). A búskomor Homo sapiens - A depresszió tüneteinek evolúciós pszichológiai értelmezése. In Gyuris P., Meskó N., \& Tisljár R. (szerk.), Az evolúció árnyoldala. A lelki betegségek és az alternatív szexualitás darwini elemzése (pp. 57-76). Budapest: Akadémiai Kiadó.

Bloch, M., Daly, R. C., \& Rubinow, D. R. (2003). Endocrine factors in the etiology of postpartum depression. Comprehensive Psychiatry, 44, 234-246.

Blom, E. A., Jansen, P. W., Verhulst, F. C., Hofman, A., Raat, H., Jaddoe, V.W., et al. (2011). Perinatal complications increase the risk of postpartum depression. The Generation R Study. BJOG: An International Journal of Obstetrics and Gynaecology, 117(11), 1390-1398.

Bottino, M. N., Nadanovsky, P., Moraes, C. L., Reichenheim, M.E., \& Lobato, G. (2012). Reappraising the relationship between maternal age and postpartum depression according to the evolutionary theory: Empirical evidence from a survey in primary health services. Journal of Affective Disorders, 142(1-3), 219-224. 
Bremner, J. D., \& Mccaffery, P. (2008). The neurobiology of retinoic acidin affective disorders. Progress in Neuro-Psychopharmacology and Biological Psychiatry, 32, 315-331.

Brummelte, S., \& Galea, L. A. (2016). Postpartum depression: Etiology, treatment and consequences for maternal care. Hormones and Behavior, 77, 153-166.

Bugental, D. B., \& Happaney, K. (2004). Predicting Infant maltreatment in low-income families: The interactive effects of maternal attributions and child status at birth. Developmental Psychology, 40, 234-243.

Cassidy-Bushrow, A. E., Peters, R. M., Johnson, D. A., Li, J., \& Rao, D. S. (2012). Vitamin D nutritional status and antenatal depressive symptoms in African American women. Journal of Women's Health, 21, 1189-1195.

Champagne, F., Weaver, I., Diorio, J., Sharma, S., \& Meaney, M. J. (2003). Natural variations in maternal care are associated with estrogen receptor alpha expression and estrogen sensitivity in the medial preoptic area. Endocrinology, 144(11), 4720-4724.

Chaudron, L. H., \& Pies, R. W. (2003). The relationship between postpartum psychosis and bipolar disorder: a review. Journal of Clinical Psychiatry, 64(11), 1284-1292.

Clutton-Brock, T. H. (1991). The Evolution of Parental Care. Princeton, NJ: Princeton University Press.

Corwin, E. J., Kohen, R., Jarrett, M., \& Stafford, B. (2010). The heritability of postpartum depression. Biological Research For Nursing, 12(1), 73-83.

Corwin, E. J., \& Pajer, K. (2008). The psychoneuroimmunology of postpartum depression. Journal of Womens Health, 17(9), 1529-1934.

Crouch, M. (1999). The evolutionary context of postnatal depression. Human Nature, 10(2),163182.

Crouch, M. (2002). Bonding, postpartum dysphoria, and social ties. Human Nature, 13(3), 363382.

Dantzer, R., O'conner, J. C., Freund, G. G., Johnson, R. W., \& Kelley, K. W. (2008). From inflammation to sickness and depression: When the immune system subjugates the brain. Nature Reviews Neuroscience, 9, 46-56.

Deecher, D., Andree, T. H., Sloan, D., \& Schechter, L. E. (2008). From menarche to menopause: Exploring the underlying biology of depression in women experiencing hormonal changes. Psychoneuroendocrinology, 33, 3-17.

Del Giudice, M. (2014). An Evolutionary Life History Framework for Psychopathology. Psychological Inquiry, 25, 261-300.

Dennis, C., \& Mcqueen, K. (2009). The relationship between infant-feeding outcomes and postpartum depression: a quantitative systematic review. Pediatrics, 123, 736-751.

Doucet, S., Dennis, C-L., Letourneau, N., \& Blackmore, E. R. (2009). Differentiation and clinical implications of postpartum depression and postpartum psychosis. Journal of Obstetric, Gynecologic Ẽ Neonatal Nursing, 38(3), 269-279.

Ellis, B. J., Figueredo, A. J., Brumbach, B. H., \& Schlomer, G. L. (2009). The impact of harsh versus unpredictable environments on the evolution and development of life history strategies. Human Nature, 20, 204-268.

Felice, E., Saliba, J., Grech, V., \& Cox, J. (2004) Prevalence rates and psychological characteristics associated with depression in pregnancy and postpartum in Maltese women. Journal of Affective Disorders, 82, 297-301.

Fisher, J. R., Hammarberg, K., \& Baker, H. W. (2005). Assisted conception is a risk factor for postnatal mood disturbance and early parenting difficulties. Fertility and Sterility, 84(2), 426430. 
Fitelson, E., Kim, S., Baker, A. S., \& Leight, K. (2011). Treatment of postpartum depression: clinical, psychological and pharmacological options. International Journal of Women's Health, 3, 1-14.

Freeman, E. W., Sammel, M. D., Liu, L., Gracia, C. R., Nelson, D. B., \& Hollander, L. (2004). Hormones and menopausal status as predictors of depression in women in transition to menopause. Archives of General Psychiatry, 61, 62-70.

Gagliardi, L., Petrozzi, A. \& Rusconi, F. (2012). Symptoms of maternal depression immediately after delivery predict unsuccessful breastfeeding. Archives of Disease in Childhood, 97(4), 355-357.

Gallup, G. G., Pipitone, N., Carrone, K. J. \& Leadholm, K. L. (2010). Bottle feeding simulates child loss: Postpartum depression and evolutionary medicine. Medical Hypotheses, 74(1), 174-176.

Gleicher, N. (2007). Postpartum depression, an autoimmune disease? Autoimmunity Reviews, 6, $572-576$.

Gluckman, P., \& Hanson, M. (2006). Mismatch: Why our world no longer fits our bodies. New York, NY: Oxford University Press.

Goyal, D., Gay, C., \& Lee, K. A. (2010). How much does low socioeconomic status increase the risk of prenatal and postpartum depressive symptoms in first-time mothers? Womens Health Issues, 20(2), 96-104.

Hagen, E. H. (1999). The Functions of Postpartum Depression. Evolution and Human Behavior, 20, 325-359.

Hagen, E. H. (2002). Depression as bargaining: The case postpartum. Evolution and Human Behavior, 23(5), 323-336.

Hagen, E. H. (2011). Evolutionary theories of depression: a critical review. Canadian Journal of Psychiatry, 56(12), 716-726.

Hagen, E. H., \& Barrett, H. C. (2007). Perinatal Sadness among Shuar Women: Support for an Evolutionary Theory of Psychic Pain. Medical Anthropology Quareterly, 21(1), 22-40.

Hahn-Holbrook, J., Dunkel Schetter, C., Chander, A., \& Hobel, C. (2013). Placental corticotropin-releasing hormone mediates the association between prenatal social support and postpartum depression. Clinical Psychological Science, 1, 253-265.

Hahn-Holbrook, J. \& Haselton, M. (2014). Is Postpartum Depression a Disease of Modern Civilization? Current Directions in Psychological Science, 23(6), 395-400.

Halbreich, U. (2005). Postpartum disorders: multiple interacting underlying mechanisms and risk factors. Journal of Affective Disorders, 88(1), 1-7.

Harris, B. (1994). Biological and hormonal aspects of postpartum depressed mood: working towards strategies for prophylaxis and treatment. Special Issue: Depression. British Journal of Psychiatry, 164, 288-292.

Hatton, D. C. (2005). Symptoms of Postpartum Depression and Breastfeeding. Journal of Human Lactation, 21(4), 444-449.

Hickey, A. R., Boyce, P. M., Ellwood, D., \& Morris-Yates, A. D. (1997) Early discharge and risk for postnatal depression. The Medical Journal of Australia, 167, 244-247.

Jeong, H. G., Lim, J. S., Lee, M. S., Kim, S. H., Jung, I. K. \& Joe, S. H. (2013). The association of psychosocial factors and obstetric history with depression in pregnant women: focus on the role of emotional support. General Hospital Psychiatry, 35(4), 354-358.

Kendell, R. E., Chalmers, J. C., \& Platz, C. (1987). Epidemiology of puerperal psychosis. British Journal of Psychiatry, 150, 16- 27.

Kendler, K. S., Myers, J., \& Prescott, C. A. (2005). Sex differences in the relationship between social support and risk for major depression: A longitudinal study of opposite-sex twin pairs. American Journal of Psychiatry, 162, 250-256. 
Kovácsné Török Zs. (2010). Szüléshez társuló pszichiátriai zavarok, különös tekintettel a gyermekágyi lehangoltság kérdéskörére. Budapest: Oriold és Társa Kiadó.

Labbok, M. H. (2001). Effects of breastfeeding on the mother. Pediatric Clinics of North America, $48,143-158$.

Logsdon, M. C., \& Mcbride, A. B. (1994). Social support and postpartum depression. Research in Nursing $\mathcal{E}$ Health, 17(6), 449-457.

Lucassen, P. J., Meerlo, P., Naylor, A. S., Van Dam, A. M., Dayer, A. G., Fuchs, E., et al. (2010). Regulation of adult neurogenesis by stress, sleep disruption, exercise and inflammation: Implications for depression and antidepressant action. European Neuropsychopharmacology, 20, $1-17$.

Macarthur, R. H., \& Wilson, E. O. (1967). The Theory of Island Biogeography. Princeton, NJ: Princeton University Press.

Markhus, M. W., Skotheim, S., Graff, I. E., Frøyland, L., Braarud, H. C., Stormark, K. M., et al. (2013). Low omega-3 index in pregnancy is a possible biological risk factor for postpartum depression. PLoS ONE, 8(7), e67617.

Mawson, A. R., \& Wang, X. (2013). Breastfeeding, retinoids and postpartum depression: A new theory. Journal of Affective Disorders, 150(3), 1129-1135.

Mcguire, M. T., \& Troisi, A. (1998). Darwinian Psychiatry. New York, NY: Oxford University Press.

Mehta, D., Newport, D. J., Frishman, G., Kraus, L., Rex-Haffner, M., Ritchie, J. C., et al. (2014). Early predictive biomarkers for postpartum depression point to a role for estrogen receptor signaling. Psychological Medicine, 44(11), 2309-2322.

Milgrom, J., Ericksen, J., Mccarthy, R.M., \& Gemmill, A.W. (2006). Stressful impact of depression on early mother-infant relations. Stress Health, 22, 229-238.

Miller, J. E., \& Huss-Ashmore, R. (1989). Do reproductive patterns affect maternal nutritional status? An analysis of maternal depletion in Lesotho. American Journal of Human Biology, 1, 409-419.

Mitterauer, M. (1994). A History of Youth. (Graeme Dunphy, trans.), American Anthropologist, 96(1), 177-178.

Murray, L., \& Cooper, P. J. (1996). The impact of postpartum depression on child development. International Review of Psychiatry, 8, 55-63.

Murray, C. J., \& Lopez, C. J. (1996). Evidence-based health policy-lessons from the Global Burden of Disease Study. Science, 274(5288), 740-743.

Nagasako, E. M., Oaklander, A. L., \& Dworkin, R. H. (2003) Congenital insensitivity to pain: an update. Pain, 101(3), 213-219.

Nesse, R. M., \& Williams, G. C. (1996). Why we get sick: The new science of Darwinian medicine. New York, NY: Vintage Books.

Nettle, D. (2009). An evolutionary model of low mood states. Journal of Theoretical Biology, 257, 100-103.

Nishioka, E., Haruna, M., Ota, E., Matsuzaki, M., Murayama, R., Yoshimura, K., et al. (2011). A prospective study of the relationship between breastfeeding and postpartum. Journal of Affective Disorders, 133(3), 553-559.

O'hara, M. W. (2009). Postpartum depression: what we know. Journal of Clinical Psychology, 65(12), 1258-1269.

Ohoka, H., Koide, T., Goto, S., Murase, S., Kanai, A., Masuda, T., et al. (2014) Effects of maternal depressive symptomatology during pregnancy and the postpartum period on infantmother attachment. Psychiatry and Clinical Neurosciences, 68(8), 631-639.

Park, E. H. M., \& Dimigen, G. (1995). A cross-cultural comparison: postnatal depression in Korean and Scottish mothers. Psychologia, 38, 199-207. 
Parry, B. L., \& Newton, R. P. (2001). Chronobiological basis of female-specific mood disorders. Neuropsychopharmocology, 25(5), 102-108.

Pipitone, R. N., Leadholm, K., Carrone, K. J., \& Gallup, G. G. (2009). Postpartum depression: bottle feeding simulates child loss. Paper presented at the annual meeting of the Northeastern Evolutionary Psychology Society. New York: Oswego.

Pope, H. G., Jr., Kouri, E. M., \& Hudson, J. I. (2000). Effects of supraphysiologic doses of testosterone on mood and aggression in normal men: a randomized controlled trial. Archives of General Psychiatry, 57(2), 133-140.

Rapoport, R. (1963). Normal Crises, Family Structure and Mental Health. Family Process, 2(1), $68-80$.

Robertson, E., Grace, S., Wallington, T., \& Stewart, D. E. (2004). Antenatal risk factors for postpartum depression: a synthesis of recent literature. General Hospital Psychiatry, 26(4), 289-295.

Rubertsson, C., Wickberg, B., Radestad, I., Hildingsson I., \& Waldenstrom, U. (2005). Depressive mood in early pregnancy and postpartum: prevalence and women at risk in a national Swedish sample. Journal of Reproductive and Infant Psychology, 23, 1-10.

Ryan, J., Scali, J., Carrière, I., Peres, K., Rouaud, O., Scarabin, P.Y., et al. (2011). Oestrogen receptor polymorphisms and late-life depression. British Journal of Psychiatry, 199, 126-31.

Ryan, J., Scali, J., Carrière, I., Peres, K., Rouaud, O., Scarabin, P.Y., et al. (2012). Estrogen receptor alpha gene variants and major depressive episodes. Journal of Affective Disorders, 136(3), 1222-1226.

Saether, B-E. (1988). Pattern of covariation between lifehistory traits of European songbirds. Nature, 331, 616-617.

Shimizu, Y.M., \& Kaplan, B.J. (1987) Postpartum Depression in the United States and Japan. Journal of Cross-Cultural Psychology, 18, 15-30.

Sit, D., Rothschild, A. J., \& Wisner, K. L. (2006). A Review of Postpartum Psychosis. Journal of Womens Health, 15(4), 352-368.

Stearns, S. C. (1992). The Evolution of Life Histories. Oxford, England: Oxford University Press.

Sundermann, E. E., Maki, P. M., \& Bishop, J. R. (2010). A review of estrogen receptor alpha gene (ESR1) polymorphisms, mood, and cognition. Menopause, 17, 874-886.

Sylvén, S.M., Ekselius, L., Sundström-Poromaa, I., \& Skalkidou, A. (2013). Premenstrual syndrome and dysphoric disorder as risk factors for postpartum depression. Acta Obstetricia et Gynecologica Scandinavica, 92(2), 178-184.

Szádóczky, E., Papp, Z., Vitrai, J., \& Füredi, J. (2000). A hangulat- és szorongásos zavarok elôfordulása a felnốtt magyar lakosság körében. Orvosi Hetilap, 141(1), 17-22.

Szekeres, Gy., Bai-Nagy, K., \& Rihmer, Z. (2015). Depressziós zavarok. In Füredi J., \& Németh A. (szerk.), A pszichiátria magyar kézikönyve (pp. 266-276). Budapest: Medicina Könyvkiadó Rt.

Taylor, V. (1996). Rock-a-by baby: Feminism, self-help, and postpartum depression. New York, NY: Routledge.

Thornhill, R., \& Furlow, B. (1998). Stress and human reproductive behavior: attractiveness, women's sexual development, postpartum depression, and baby's cry. In A. P. Moller, A. P., Milinski, M., \& Slater, P. J. B. (Eds), Stress and behavior (pp. 319-369). San Diego, CA: Academic Press.

Thornhill, R., \& Thornhill, N. W. (1989). The evolution of psychological pain. In Bell, R. W., \& Bell, N. J. (Eds), Sociobiology and the social sciences, (pp. 73-103). Lubbock, TX: Texas Tech University Press.

Tracy, M. (2005). Postpartum Depression: An Evolutionary Perspective. Nebraska Anthropologist, $20,38-54$.

Tringer L. (2010). A pszichiátria tankönyve. Budapest: Semmelweis Kiadó. 
Trivers, R. L. (1972). Parental investment and sexual selection. In B. Campbell (Eds.), Sexual selection and the descent of man, 1871-1971 (pp. 136-179). Chicago, IL: Aldine.

Vigod, S. N., Villegas, L., Dennis, C. L., \& Ross, L. E. (2010). Prevalence and risk factors for postpartum depression among women with preterm and low-birth-weight infants: a systematic review. BJOG: An International Journal of Obstetrics E Gynaecology, 117(5), 540-550.

Warner, R., Appleby, L., Whitton, A., \& Faragher, B. (1996). Demographic and obstetric risk factors for postnatal psychiatric morbidity. British Journal of Psychiatry, 168, 607-611.

Warren, Y., \& Williamson, E. A. (2004). Transport of dead infant mountain gorillas by mothers and unrelated females. Zoo Biology, 23, 375-378.

Wisner, K. L., Chambers, C., \& Sit, D. K. (2006). Postpartum Depression. A Major Public Health Problem. Journal of the American Medical Association, 296(21), 2616-2618.

Wood, J. W. (1994). Dynamics of Human Reproduction: Biology, Biometry, Demography. New York, NY: Aldine De Gruyter.

Woods, N., Smith-Dijulio, K., Percival, D., Tao, E., Mariella, A., \& Mitchell, E. (2008). Depressed mood during the menopausal transition and early postmenopause: observations from the Seattle Midlife Women's health Study. Menopause, 15, 223-232.

Workman, J. L., Barha, C. K., \& Galea, L. A. (2012). Endocrine substrates of cognitive and affective changes during pregnancy and postpartum. Behavioral Neuroscience, 126(1), 54-72.

\section{EVOLUTIONARY THEORIES OF POSTPARTUM DEPRESSION}

\section{SZITA, BERNADETT}

Postpartum depression (PPD) is a serious international public health issue affecting approximately 10-15 percent of mothers worldwide. Known risk factors include: low perceived social support, low socioeconomic status, preterm or unhealthy newborns and maternal lifetime history of mental health problems. The etiology is not fully understood, both biological and psychosocial factors may contribute to the development of a PPD. Evolutionary theorists suggest that PPD is not a dysfunction, but an adaptive mechanism that signals a potential reproductive fitness cost to the mother and prompts her to make a decision whether to continue or to stop caring for the offspring. Evolutionary theory also predicts that a mother does not automatically invest in all of her children but constantly evaluates the fitness costs and benefits of it. In this paper we overview the most relevant evolutionary approaches to PPD with an emphasis on current research findings that verify or refute the theoretical explanations on this topic.

Keywords: postpartum depression, evolutionary psychology, parental investment, reproduction, infant care 